This item was submitted to Loughborough's Research Repository by the author.

Items in Figshare are protected by copyright, with all rights reserved, unless otherwise indicated.

\title{
Hosts and guests, guests and hosts: British residential tourism in the Costa
} del Sol

PLEASE CITE THE PUBLISHED VERSION

PUBLISHER

(C) Ashgate

VERSION

AM (Accepted Manuscript)

LICENCE

CC BY-NC-ND 4.0

\section{REPOSITORY RECORD}

O'Reilly, Karen. 2019. "Hosts and Guests, Guests and Hosts: British Residential Tourism in the Costa Del Sol". figshare. https://hdl.handle.net/2134/5662. 
This item was submitted to Loughborough's Institutional Repository (https://dspace.lboro.ac.uk/) by the author and is made available under the following Creative Commons Licence conditions.

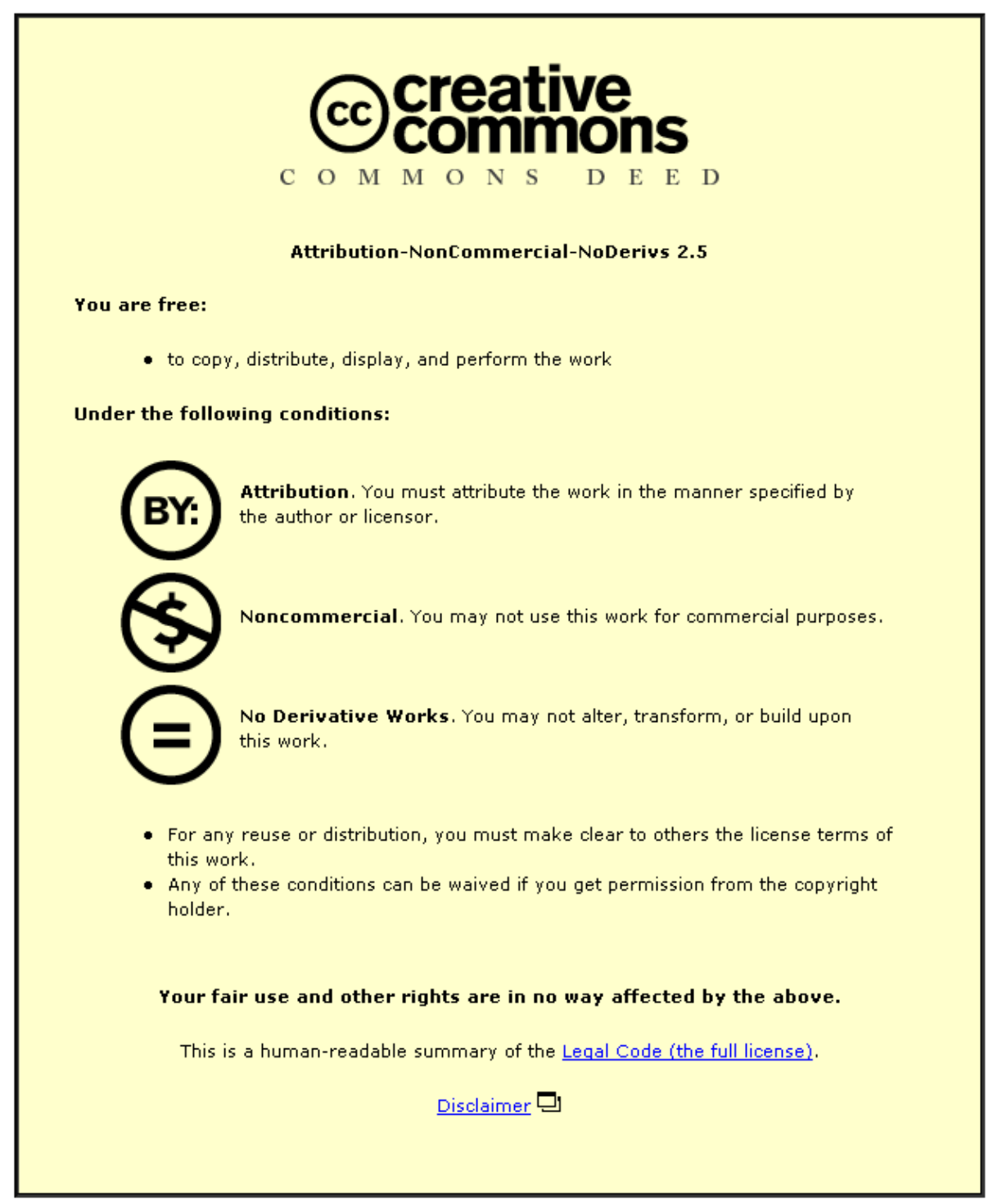

For the full text of this licence, please go to: http://creativecommons.org/licenses/by-nc-nd/2.5/ 
O'Reilly, K (2009) Hosts and Guests, Guests and Hosts: British residential tourism in the Costa del Sol, in Obrador Pons, P., Crang, M. and Travlou, P. (eds) Cultures of Mass Tourism: Doing the Mediterranean in the age of banal mobilities. Farnham: Ashgate.

\section{Chapter 7}

Hosts and Guests, Guests and Hosts: British residential tourism in the Costa del Sol ${ }^{1}$

\section{Karen O'Reilly}

When Pau Obrador first asked if I would like to contribute to this book on tourism cultures in the Mediterranean I immediately said yes. I have been studying and writing about British migrants in Spain for over ten years, and have been a member of the community as a second-home owner or peripatetic migrant for much of that time ${ }^{2}$. Most of my work has been at pains to point out that these migrants do not see themselves as tourists. They mark themselves out in opposition to tourists. They say 'we live here' or 'we are here to stay'. They talk about tourists as 'other', as a nuisance, as 'them not us', as the visitors who come and take up their time and want to be shown around, as family who think they (the migrants) are always on holiday (O’Reilly 2003).

On the other hand it has been undeniable in everything I write that this is a tourism-informed mobility (cf. Williams and Hall 2002). The migrants live in a tourist place, alongside tourists, sharing in tourist spaces and activities, spending time with tourists at work and play, often living leisured lives marked by tourist activities. British

\footnotetext{
${ }^{1}$ I would like to dedicate this paper to Valerie, who very sadly and unexpectedly passed away since this paper was first drafted, demonstrating rather starkly the materiality of our bodies. She is missed, and I hope I have done justice to her sincere attempts to settle in Spain.

Research for the paper was funded, between 2003 and 2005, by the Economic and Social Research Council of Great Britain (Grant No. R000223944).

${ }^{2}$ There are currently 600,000 registered British living in Spain, and one can safely estimate that this only represents a third of those who actually live there most of the year. If all British in Spain were registered they would be the largest minority group in the country. See www.ine.es
} 
migration to Spain has been concentrated very much in the coastal zones which have been developed for tourism, with the infrastructure, tourist objects, activities, and services tourists are deemed to require. This argument has been pursued elsewhere (see O’Reilly 2003), but what continues to fascinate me about the Brits in Spain and sustained me in writing about this migration on and off for so many years, is the incredible contradictions that mark the migrants's lives, their identities, their experiences, dreams, aspirations, and frustrations. Their relationship to Spain is circumscribed by the fact that for them Spain symbolizes holiday and escape (and tourism), but they insist they are not tourists themselves. They declare a love of Spain while reminding each other 'we are guests here'. They say 'we live here' and yet go 'home' regularly. They say they want to integrate in Spain yet make little effort to put such aspirations into practice. They express a love of Spain but often seem to have a vague understanding of its culture and customs (O’Reilly 2000 and 2007, King et al 2000, Rodriquez et al 1998).

Yet even as I write these things I know I am making a lie of other things I have written, where I have argued that many British in Spain do not go home all the time, or that most do want to integrate and do try to settle (O’Reilly 2007). I have had to distinguish those who live in Spain all year round (what I have called full residents) from those who spend some of the year in Spain (seasonal, peripatetic or returning residents). And even then there are those who are simply experiencing life in Spain for a while and those who have committed themselves emotionally and financially and cannot easily return to the UK. There are some who spend a little time each year in Spain, but consider UK to be home, and others who live in Spain but regularly spend a little time 'back home’ (O’Reilly 2000). A key problem with ethnographic research is 
that one becomes so familiar with individual people and individual lives it becomes impossible to continue to talk both generally and honestly about a group.

But however much I go round and round in circles trying to understand and explain these people and their problems and pleasures, intentions and impacts, it is impossible to deny their relationship to tourism and the way cultures of tourism impact on their lives. It is also impossible to deny the impact their cultures of tourism have on the surrounding areas, people and things. I am beginning to think that the term 'residential tourism', that many Spanish use to describe them, is actually a useful term after all, though I have avoided it because the migrants themselves argue against it. There is an extent to which all these migrants are turning tourism into a way of life and an extent to which the very contradictions outlined above are the very core of what they are and how they live ${ }^{3}$.

\section{Things and Actions: Materiality and Performance}

Usually I like to work inductively, entering the field, observing, joining in, and learning about people's lives from their own perspective before stepping out, seeing what sense I can make of it all for others, or how what I have witnessed and experienced can be translated or made sense of using theories and concepts to frame the various general themes I wish to explicate (O’Reilly 2005). However, for this chapter I have proceeded somewhat counter-intuitively. In the introduction the editors of this book describes a new approach to tourism and culture that accounts for the relationships between people and things, the activities and objects of tourism, that understands the outcome of this

\footnotetext{
${ }^{3}$ There is an extent to which the argument in this paper is relevant for other North European migrants in Spain's coastal zones. However, research with these other groups has tended to focus exclusively on retirement migrants and to employ quantitative methods, so the applicability for this thesis to those groups remains a question (see Aledo 2005, Casado-Díaz et al., 2004, Rodríguez et al 2005, Warnes et al 2005).
} 
interaction in terms of performance, and considers the impact of tourism cultures on objects and people. I decided to explore this new theoretical paradigm to see if there was anything that could act as sensitizing concepts that I might take back to the field and thereby 'see' things I had not seen before.

Haldrup and Larsen (2006), argue that materiality and material objects need to be incorporated into cultural accounts of tourism; that we need to re-examine the way things around us shape and are shaped by practice. This literature argues that the ‘cultural turn’ with its emphasis on thinking, imagining and representing, treats things as signs rather than concrete objects; whereas actions are only actionable because of the existence of things and technologies. They suggest that the world of leisure is not merely a human accomplishment, and seem to imply that things also accomplish. It seems to me this argument is a bit like Emile Durkheim's about the real nature of society, by saying people make and use things but then things come to have a life of their own - inasmuch as some things are doable and others not. I think this is partly true. Modern telecommunications technology, for example, has led to certain forms of communication, and therefore social life, that could not have been imagined in the past. On the other hand, mobile phone companies, for example, did not foresee the extent of the use of text-messaging and the impact that has had on young people's lives but have since adapted their technologies to take this into account, adding photo messaging and emoticons. This argument is not to deny that things have 'sign-value' but to acknowledge they also have ‘use-value’.

In his fascinating introduction to the field of tourism, Adrian Franklin (2003) contends that tourism's objects can have a life of their own or can impact in unpredictable ways. John Urry's (1990) important attention to the tourist gaze, he 
believes, does not go far enough. Tourists do not just look upon, they buy, carry, transport, experience and use objects. In order to illustrate the role of objects, Franklin describes R. Ewins's study of bark cloth souvenirs in Fiji. Bark cloth, or tapa, was originally made from native plants and used in Fiji for clothing, bedding and ceremonial purposes. It was ornately decorated and also light to carry so was an ideal souvenir for the early tourists who arrived by steam ship. As a result locals started to make smaller pieces specifically for this market. However, although it has been common to argue that tourism thus commoditizes, trivializes, and ultimately extinguishes local cultures, Ewins argues that this market in tapa has actually ensured the continuation and even intensification of a tradition and economic activity which might otherwise have been lost as a result of economic and cultural competition from migrant Indian businesses.

These themes are not restricted to tourism studies by any means. In social anthropology Tim Ingold (1995, 2000) has been developing an argument that things evolve as the outcome of the interrelationship of the human and non-human worlds; that the design of a thing is not so much driven by the human imagination as by its innate properties and malleability. Humans, by working on the world become part and parcel of the transformation of the system of relations within which both the human and the thing come into being. Here natural selection and cultural selection work hand in hand, so that like genetic dispositions, ideas are weeded out, adapted and developed over time and through the mutual weaving of people and materials.

In philosophy, Bruno Latour (2000) has been arguing that all human society is built with things. This is not simply to say that the material matters but to acknowledge that in fact there is no material versus human; humans are material and the material, as soon as it enters the social world (by being seen, thought about, used or remembered), 
ceases being an object. Rather than objects and subjects, for Latour there are only trajectories and transformations, paths and trails. Things take on the impression of our use, and social relations become mediated by things. But here things are mediators not intermediaries. In other words the things make or form social relations. However, at the same time these things remain frail, amendable.

Parallel to the development of ideas outlined above, others have been calling for more attention to the dynamic nature of place construction, to acknowledge change, fluidity and creation. Simon Coleman and Mike Crang (2002) argue that, contrary to the way they are portrayed in earlier tourist literature in which place $=$ culture $=$ people, and where tourists are often depicted as the cause of breakdown of this healthy relationship, places are in fact fluid, dynamic, multicultural, and created through performance. Again, these authors acknowledge the role the concept of the tourist gaze, has played but recognize its limitations in looking only at what is seen, ignoring what is done and what is seen and done back. It is through embodied performance, they contend, that places (and lifestyles and cultures) are effected. They argue for the telling of spatial stories. 'We want to open up the possibilities of understanding tourism as an event that is about mobilizing and reconfiguring spaces and places, bringing them into new constellations and therefore transforming them.' (Colemand and Crang 2002: 10).

What I take from all this is the need to rethink what people do and with what on the Costa del Sol, and to ask what is the role of things, bodies and performance in residential tourism. For the rest of this paper I will respond to the call to consider the dynamic relationship between people and things, and the ways in which people actively and bodily involve themselves in the material world. I concede I have been guilty of seeing tourism purely as a system of signs, adding meaning to people's lives through 
what it signifies (pleasure, escape, contact with the Other, and so on). I have ignored the material in favour of the ideal factors in enabling and promoting first tourism then residential tourism, and neglected to consider residential tourism not as a state but as a continual performance, a balancing act of here and there, utopia and reality, tourism (travelling) and arriving.

The next two sections of this paper explore the material factors that have enabled and promoted tourism-related expectations and activities, thus incorporating materiality into the cultural account (Haldrup and Larsen 2006). Here I also acknowledge the way humans transform the world around them through their actions, and thus the co-creation of the material world and tourism culture in the Costa del Sol through transformation and performance (Coleman and Crang 2002). I then proceed to examine the complex material cultures that are woven into the everyday lives of British residents in Spain and demonstrate how it is the very contradiction between residence and tourism that enables residential tourists to live life as a kind of escape (sometimes less satisfactorily than others, see O’Reilly 2007). Residential tourism thus entails a subtle and continual balancing act, which is managed, practiced or performed on a daily basis especially through the act of being both hosts and guests.

\section{Materiality of tourism}

Regardless of Franklin's (2003) argument that tourism is not so much an escape from modernity as an aspect of it, I remain convinced that British residential tourism is driven by a desire to escape, a search for the authentic, for the past and for community. I am convinced of this because this is the way residential tourists frame their motivations. They continually disparage Britain (which is unusual for migrants) and illustrate the pull factors that attract them to Spain. According to a whole range of studies (Ackers 
and Dwyer 2004, Aledo 2005, Casado-Díaz et al. 2004, O’Reilly 2000 and 2007, Rodríguez et al. 2005, Warnes et al. 2005) their main reasons for moving are: for 'quality of life', the pace of life, or for a slower, relaxed life; the climate/ sun (which enables health and relaxation); the cost of living, cheap property (enabling early retirement and/or a better lifestyle); a business opportunity (to fund a better life); for a better life for the children; the culture (which they believe includes a sense of community, respect for the elderly, safety, and less crime); closeness to home, and other ties and connections; the desire to leave their home country (because of high crime rates, and too many immigrants!, or to escape the rat-race, failing businesses, unemployment, or the political situation); and to go somewhere 'you can be yourself'.

One could argue that the Costa del Sol provides all these through imaginings, representations and the social construction of space (O'Reilly 2000). But it is undeniable that first of all the Costa del Sol was able to provide many things materially. The geographical area has innate properties humans work with (Ingold 2000). After all it has not been called the sunshine coast for nothing: it boasts an average of nine hours of sunshine a day. The sea is clear, blue and warm and the sands are golden. The heat of the summer especially, combined with the relatively low humidity mean no one goes anywhere in much of a hurry and the Spanish tendency to worry about things tomorrow rather than today is more in evidence in Andalucía than the rest of Spain. The coastal fishing villages and the surrounding white villages, symbolic of traditional unspoilt community life, were idyllic locations in which to locate the developing mass tourism of the late 1960s. Trail-blazing travellers, intellectuals and artists had already visited and recorded their experiences for others, including, for example, Ernest Hemingway and Gerald Brenan and other 'professionals' from diverse parts of the world (Fraser 
1973). Tourists then merely followed these well-worn paths to established destinations (MacCannell 1976), seeing how others have used these spaces, going there and thus transforming them again in the process.

Of course, the gradual increase in visitor numbers together with the advent of the package holiday led to an unprecedented period of development in the 1970s. Some would say the area was spoiled, but for the tourists this also meant that materially they could still go to warm seas, golden sands, white villages, Mediterranean food and wine, and now with a built in infrastructure that made the whole thing easier, and it was still cheaper than home. Tourism theories that describe visitors sampling a little bit of the culture and the way of life without having to become too adept at the culture, without learning the language, and so on, really made sense in this situation (Boorstin 1964, MacCannell 1976). Indeed one could describe Costa del Sol tourism as the archetypal mass seaside tourism of the 60s and 70s. The Costa del Sol, I would argue, has been created for and by travel, tourism and now residential tourism more than any other tourist space. And of course, these types of mobility in turn have emerged out of the use and creation of this space for these purposes Haldrup and Larsen 2006). Even Coleman and Crang have to agree in the midst of their argument against such a perspective, that 'if one observes the sprawl of concrete along the Mediterranean coast with its assorted “authentic English pubs”, the vision of tourism as homogenizing and destroying local particularity might seem to have some credibility’ (2002: 2).

\section{Materiality of residential tourism}

Materially, things have continued to develop and change in both the UK and in Spain. In 1975, the death of Franco removed many disincentives to migration for Europeans. Relations between Britain and Spain gradually became more Europeanized culminating 
in the free movement of individuals introduced in the Maastricht Treaty in 1992. The growth of the annual holiday combined with an increase in expendable wealth for many Europeans during the 1970s and 1980s, especially relative to Spain (Bedarida 1991), and owning a second home became the ultimate consumer aspiration in the newly affluent societies (Svensson 1989). A massive growth in the UK property market in the 80s meant people could sell homes at huge profits and buy upmarket and cheaper in Spain, thus funding a new lifestyle in the bargain and, even during the subsequent property crash and downturn, the exchange rate between the pound sterling and the peseta remained favourable to Brits. Later, rural and inland tourism, and then what several Spanish academics and commentators have already called residential tourism (here referring to second home ownership and long-term tourism, Aledo and Mazón, 2004) were actively encouraged by Spain’s tourist board to compensate for the seasonal and regional nature of tourism. This active promotion of property purchase and of tourism to rural areas has gone some way to encouraging the rural and inland migration of Europeans during the 1990s, thus taking on something of a life of its own (Franklin 2003). Costa del Sol residential tourism is both co-created and co-creating. Secondhome owners were joined by retirees, looking to spend their third age (at least some of the year) in comfortable and reasonably priced surroundings. These were joined by bar and restaurant owners and others who provided services for the more settled migrants and tourists. As time has gone by younger migrants with families have joined the earlier migrants and now British are living in Spain in all manner of flexible ways. All this has been rehearsed elsewhere (King et al 2000, O’Reilly 2000, Casado Diaz et al 2004). I have reiterated it here in acknowledgement of the relevance of material (as opposed to merely ideal) factors in residential tourism. 
Of course there are also more general material conditions which impact on residential tourism. We can summarize these as follows: globalization, increased interconnectedness and time-space compression (Giddens 1990); increased and turbulent forms of geographical mobility and a general fluidity in contemporary lifestyles (Papastergiadis 2000, Urry 2000, Bauman 2000); the rise of information technology and the network society; the spread of mass communications, cheap and expanded air and road travel; flexibility in labour markets, the end of the 'job for life', more working from home, the ability to live and work in different places, and with these, increased leisure time in affluent societies, extended holidays, and early retirement (Pollert 1991, Michie and Sheehan 2003). On a more negative note, increases in redundancies, temporary work, insecurity, and struggling small businesses encourage risk-taking behaviours such as working cash in hand (O’Reilly 2007); and finally migration chains, and the role of intermediaries - estate agents, financial institutions, mass media - promote and enable migrations (Castles and Miller 2003).

\section{Utopian Dreams}

Increasing numbers of residential tourists, then, are attempting to emulate the tourisminformed lifestyle in more and more flexible ways. The one thing that has remained continuous is the description of the place they are going to as escape, even as materially things have changed. But not only do they describe escape, they live and perform it on a daily basis. They tend to avoid routine, to focus on leisure rather than work, to work informally or casually, and to deny routine pressures and strains. They spend a lot of time with holiday-makers and thus avoid serious conversations, and they are loathe to have their lives structured or controlled, often avoiding registering with the town hall or paying taxes (O’Reilly 2000 and 2003). In other words their lifestyles and (material) 
cultures are effected in relation to material factors through embodied performance (Coleman and Crang 2002).

MacCannell (1976) famously defined tourism in terms of the existential quest for the authentic, arguing that as modern life becomes increasingly adulterated the desire for the real or original increases. Now, many tourism theories have challenged this perspective, but only in as much as it is based on an assumption that there is a real, authentic or original to experience. Authenticity can only be staged if there is such a thing to stage, and preserve (Coleman and Crang 2002). Franklin (2003: 24) goes further, arguing that tourism is not so much a desire to escape modernity as a means to take part in it; 'the quintessential expression and performance of modern life'. But I think even if we accept (as we must) that cultures are not bounded, coherent or firmly located, and that tourism is as much part of the everyday as an attempt to escape it, nevertheless we must still acknowledge that British residential tourists describe a search for escape, community, the past, the real, the slow, and the uncomplicated.

I do not think that this escape is necessarily an escape from modernity or from urban lifestyles (that assumes that life actually was once better); I think it is simply that there is a timeless idea that life was once better, or that it could be better. The themes are the same as far back and as broadly as the timeless theme of utopia. John Carey (1999) has traced utopia as a genre as far back as ancient Egypt. Utopias can be forecasts, dreams, stories, descriptions, the imaginary voyage, the earthly or heavenly paradise, the political manifesto, and of course the search for Eldorado. Carey believes utopias express a desire to replace the world that we know, whatever that world looks like, but they do share key themes which we can certainly recognize in residential tourism: the desire to get rid of criminals (or to move away from them), a search for 
selflessness and community spirit, a search for quality of life, tranquillity and beauty (and sometimes achieving this by looking inward and ignoring the world around you). Utopians are fair and reasonable and true to 'man's' true nature (whatever that is taken to mean), and utopias often look back to the past or forward to a better future, and include transit to some other place, 'where something can be learned about how life should be lived' (Carey 1999: 1).

But utopia is nowhere. It cannot exist in reality. Tourism works because (for some types of tourism) it is about seeing this other world for a while but then going back to reality; gazing on it but staying safe. Residential tourism works as long as the participants remain in but not in, of but not of, home but not home, neither here nor there. In other words the contradictions are essential: they explain the lifestyle. Residential tourism is managed by continually balancing tourism and residence, and one of the key ways this is achieved is through acting as hosts to their guests. It is fascinating to see this in action. Residential tourists learn all about the area, show their visitors around, share their knowledge, and act in many ways as tour guides. At the same time, of course, they act as tourists themselves, joining in activities and gazing on sights and landscapes. The act and performance of touring, showing people around, taking part in tourist activities marks them as both hosts and guests.

\section{Hosts and Guests}

In 2001 Mike and Valerie, who were both then in their 50s decided to quit their jobs, sell their house and move to Malaga for a better life. They calculated that if they sold their house in the UK and bought a cheaper one in Spain they could live carefully off the remainder of their capital until they reached retirement age and could claim small pensions. They bought a house in the countryside, partly because Mike wanted a big 
garden to work on and partly because they could not afford anything very close to the coast. They spoke very little Spanish before they arrived but had every intention to learn the language once they had settled. To an extent they assumed that living in the countryside would mean they would learn the language simply by being there and having to use it. In fact being early retired meant that their contact with Spanish people was restricted to shop assistants and waiters and the occasional health or council official. They found that it was not at all easy to just go out and get to know Spanish locals. On the other hand, given that there are many British people living in the area, it was very easy to meet their own compatriots, make friends, get help and advice, and generally build up a good network of friends and acquaintances who all spoke English. This is not what they had intended, of course, it just kind of happened. They continue, even now, to attend Spanish classes regularly, and Valerie has an arrangement with her dentist's assistant whereby they meet regularly for Spanish and English conversation. But Valerie is sad that the friendship has not developed further and that they seem to have made no real Spanish friends, other than people to simply nod and say 'hello' to in the neighbourhood.

I have explained this lack of integration as being the result of a combination of factors: many British in Spain are retired and therefore do not meet Spanish people in their daily lives in order to build relationships and acquire good language skills; many of those who do work, work in the tourist industry or with other migrants (in estate agencies, bars, timeshare sales, and property maintenance); there are so many tourists and other migrants in the area it is easier not to speak Spanish than to learn it; and as more younger migrants settle in the area the more they provide work for themselves in the form of businesses offering a range of services to both the settled migrant 
community and the tourists. It is now possible to get your hair cut and styled, your dog's hair cut and styled, have an extension built on your house, have your garden maintained, buy a car, get your pool cleaned, and have your legs waxed without speaking a word of Spanish (and perhaps without even meeting a Spanish person). On top of that one can receive British or English-language daily papers and even watch, through satellite or cable, all the British free view or English-language television channels.

Mike and Valerie spend their time engaged in a multitude of activities. They are members of a gardening club and an amateur theatre group, Valerie does line-dancing and runs a small brownie-guide club, they play tennis and are members of a birdwatching group. All of these groups are English-speaking and all are made up of a mixture of (mostly English) migrants, seasonal migrants and sometimes tourists or visitors. However, one activity they engage in above all others is being hosts to their long stream of visitors from the UK. Like many of the British who are settled in Spain they complain about the cost, effort, strain and interruption to their routine caused by the fact that one can ensure above all else that when you live in Spain people will visit you. In a survey I conducted amongst those who live in Spain 97 per cent said they have visitors from home and some stay up to a few months at a time. As one man put it half jokingly:

It comes to something when you've got to move two thousand miles to be popular, but all of a sudden all these friends that I haven't spoken to for years are suddenly, “oh can we come and stay with you for a week?” And I go “sorry, who are you again?” and they say something like “Oh, I was behind you in the queue in the bank once. You know me!”

The contradiction is in the fact that although they complain about it, they do it all so well and even seem to encourage the activity. I would consider visiting friends 
and relatives to be a material fact of living in Spain for British migrants, and the way this is managed can be understood as a performance of the balance between hosts and guests, between living and touring, being of but not of the society they live in.

Valerie and Mike assiduously collect tourism leaflets and brochures and general information about their area to the extent that they would make tour guides appear uninformed. Valerie knows where the tourist office is in her town (though it took me weeks to locate it), and regularly picks up the newspaper, Malaga Rural, which richly describes local villages and events. She is familiar with the location of several national parks and public gardens in her area. She knows exactly when what ferias are on in which village, likes to go with visitors to as many as possible, and is able to explain the meanings of a range of religious ceremonies and processions. She knows the date of Coín's Festival de los Naranjos, and the best spot to witness the celebration of the Noche de San Juan, which takes place in coastal towns on the longest day of the year. She loves to take visitors to Mijas's International Day. Mike knows the fastest or most scenic routes to historic and other tourist sites, the viewing places to stop at en route, and the location of the best car parks. He can take visitors swimming in the reservoirs at El Chorro Gorge and to see the place where von Ryan's Express was filmed, in the space of one day, passing a café on the way there, a restaurant at midday, and a café on the way back. Valerie and Mike have located Roman baths in Antequera, know when to spot griffon vultures in El Torcal, and enjoy taking visitors on the costal walk from La Cala del Moral.

Valerie and Mike believe that learning about local places and events, histories, geographies and cultures, makes living in Spain more interesting for themselves. They explain that having many visitors throughout the year can become tedious without new 
places to visit. Also, visitors tend to return more than once and so need new places to see themselves. In this way Valerie and Mike are merely being good hosts, sharing and describing their home. However, being retired and living leisured lifestyles, they are thus free to join their tourists in their touring and so, like many of the migrants in Spain, they try to treat the time when their visitors come as a bit of a holiday and sight-seeing tour themselves. To this extent they are tourists.

But Valerie, Mike and their visitors are never really part of what they see and do. For a start locals do not go to lots of ferias and fiestas, just their own, especially when it comes to the Romería or the Easter parades. And when residential tourists and their visitors stand, as I have done many a time, watching a procession or a Romería, or taking part in a giant country picnic, they tend to feel out of it, lonely while in the thick of things, left out. They remain strangers, for whom nothing can be taken for granted and all is open to question. As Mike explained: 'you can read all you like about the different things, but you are never really sure what is really going on, and you always feel like an outsider really'. For all migrants, the world around them is a field of adventure and a topic of investigation (Schutz 1971) and Mike’s and Valerie’s studying and attempts to take part are merely more of that. The more they learn and try to engage the more like strangers they become.

Valerie and Mike, like many migrants in Spain, also complain about being hosts to so many guests. It can get boring and tedious, and costly, especially if people stay too long. And, after all, the tension between trying to live somewhere and trying to be on holiday is experienced as any tension, and is never quite comfortable. They tend to eat out a lot when visitors come, and women thus complain that it is impossible to maintain a healthy diet. They spend a lot of money on fuel taking visitors around. Mike says he 
sometimes feels like a taxi-driver. Valerie gets worn out with cleaning the house in preparation for guests who treat her home like a hotel. They want to continue to do their routine things - like gardening and learning Spanish - and have to fit these in around tourist activities. But this performance of hosts and guests is the daily practice of balancing tourism and residence and cannot be resolved.

Another aspect of this balancing act between home and away, touring and residence is that many British migrants in Spain return to the UK regularly, where they are reminded they are now away from home in what used to be their 'normal' surroundings. My survey of 340 British residents was only distributed to those who consider they live in Spain and yet, nevertheless, 64 per cent of respondents return to the UK each year and a quarter of those had returned for more than one month in the past year. Mike and Valerie go back each summer, to escape the intense heat in Andalucía at that time of year. Valerie goes for a couple of months. It gives her time to see her mother and her grandchildren and to escape what she calls the trials and tribulations of living in Spain: the surprising cold and damp in the winter, the frequent power cuts, the way her access road gets flooded each winter, the cracks that are appearing in her bedroom walls as a result of extreme weather conditions, the stray dogs that drive her mad with their barking at night, and constant frustration at her lack of Spanish language skills. Mike goes for just a few weeks as he enjoys working on his garden in Spain and hates to leave it too long. Also, he feels too much like a visitor and thus a nuisance in the UK. Valerie, on the other hand, feels a little bit as if she is going home again each time. 


\section{Conclusion}

In conclusion, it seems residential tourism (a term I have avoided over the years) might be the one best suited to explain British migration to Spain's coastal areas. Residential tourism is an oxymoron, a contradiction in terms, and British residential tourists practice, perform and experience this paradox on a daily basis. Recent developments in philosophy, anthropology, cultural studies and tourism that focus on the interrelationship of people and things, that explore actions and the performance and cocreation of cultures and places, help us understand residential tourism as the daily practice of a contradiction. Residential tourism is an escape attempt, a utopian dream, and Spain's coasts materially offer idyllic locations to which to escape. The creation of these spaces as sites for pleasure and leisure has then provided the infrastructure that enables residential tourism. Later, supported by a host of material factors, the settled tourists themselves further facilitate the migration of others. But utopias are nowhere and cannot exist in reality, so the escape attempt has to be managed on a daily basis by balancing competing fields (home/away, tourism/residence). One of the most stark ways this is witnessed is through the practice of hosts and guests: residential tourists are both.

\section{References}

Ackers, L. and Dwyer, P. 2004. Fixed laws, fluid lives: the citizenship status of post-retirement migrants in the European Union. Ageing and Society, 24(3), 451-75.

Antonio-Tur, A. 2005. Los otros inmigrantes: residentes europeos en el sudeste español, in Movimientos Migratorios Contemporáneos, edited by J. Fernández-Rufete and M. Jiménez. Murcia: Fundación Universitaria San Antonio, 161-80.

Bauman, Z. 2000. Liquid Modernity. Cambridge: Polity Press. 
Bedarida, F. 1991. A Social History of England 1851-1990. 2nd Edition. London: Routledge.

Boorstin, D. 1964. The Image: A guide to pseudo-events in America. New York: Harper.

Carey, J. 1999. The Faber Book of Utopias. London: Faber and Faber.

Casado-Díaz, M.A., Kaiser, C. and Warnes, A.M. 2004. Northern European retired residents in nine southern European areas: characteristics, motivations and adjustment. Ageing and Society, 24(3), 353-381.

Castles, S. and Miller, M. 2003. The Age of Migration. 3rd Edition. Hampshire and New York: Palgrave Macmillan.

Coleman, S. and Crang, M. 2002. Tourism. Between Place and Performance. Oxford: Berghahn.

Franklin, A. 2003. Tourism: An Introduction. London: Sage.

Fraser, R. 1973. The Pueblo. A Mountain Village on the Costa del Sol. London: Allen Lane..

Giddens, A. 1990. The Consequences of Modernity. Stanford, CA: Stanford University Press.

Haldrup, M and Larsen, J 2006. Material cultures of tourism. Leisure Studies, 25(3), 275-89.

Ingold, T. 1995. Building, dwelling, living: how animals and people make themselves at home in the world, in Shifting Contexts, edited by M. Strathern. London: Routledge, 57-80.

Ingold, T. 2000. Making culture and weaving the world, in Matter, Materiality and Modern Culture, edited by in P.M. Graves-Brown. London: Routledge, 50 - 71. 
King, R., Warnes, T. and Williams, A. 2000. Sunset Lives: British Retirement to Southern Europe. Oxford: Berg.

Latour, B. 2000. The Berlin key or how to do words with things, in Matter, Materiality and Modern Culture, edited by in P.M. Graves-Brown. London pp.10-21

MacCannell, D. 1976. The Tourist: A New Theory of the Leisure Class. New York: Schocken.

Michie, J. and Sheehan, M. 2003. Labour market deregulation, 'flexibility’ and innovation. Cambridge Journal of Economics, 27(6), 123-43.

O’Reilly, K. 2007. Intra-European migration and the mobility-enclosure dialectic. Sociology, 41(2), 277-93.

O’Reilly, K. 2005. Ethnographic Methods. London: Routledge.

O’Reilly, K. 2003. When is a tourist? the articulation of tourism and migration in Spain’s Costa del Sol. Tourist Studies, 3(3), 301-17.

O’Reilly, K. 2000. The British on the Costa del Sol. London: Routledge.

Papastergiadis, N. 2000. The Turbulence of Migration: Globalization, Deterritorialization and Hybridity. Cambridge: Polity Press.

Pollert. A. 1991. Farewell to Flexibility. Oxford: Basil Blackwell.

Rodríguez, V., Fernández-Mayoralas, G., Casado-Díaz, M.A. and Huber A. 2005. Una perspectiva actual de la migración internacional de jubilados en España, in La Migración de Europeos Retirados en España, edited by V. Rodríguez, M.A. CasadoDíaz and A. Huber. Madrid: CSIC, 15-46.

Rodríguez, V., Fernández-Mayoralas, G. and Rojo, F. 1998. European retirees on the Costa del Sol: A cross-national comparison. International Journal of Population Geography, 4 (2), 91-111. 
Schutz, A. 1971. The stranger: an essay in social psychology in Alfred Schutz: Collected Papers II: Studies in Social Theory, edited by A. Broderson. The Hague: Martinus Nijhoff.

Svensson, P. 1989. Your Home in Spain. $2^{\text {nd }}$ Edition. London: Longman.

Urry, J. 2000. Sociology Beyond Societies: Mobilities for the twenty-first century. London: Routledge.

Urry, J. 1990. The Tourist Gaze. London: Sage.

Warnes, T., King, R. and Williams, A. 2005. Migraciones a España tras la Jubilación, in La Migración de Europeos Retirados en España, edited by V. Rodríguez, M.A. Casado-Díaz and A. Huber. Madrid: CSIC, 47-68.

Williams, A. and Hall, C.M. 2002. Tourism and Migration: New Relationships Between Production and Consumption, London: Kluwer Academic Publishers. 